\title{
The Ferdinande Johanna Kanjilal Travelling Fellowship
}

The Travelling Fellowship has been established from funds donated by G. C. Kanjilal, in memory of his wife, Ferdinande Johanna.

The Fellowship, value $£ 2000$, will be awarded every two years by the Royal College of Psychiatrists to further the experience of senior trainees in psychiatry from countries overseas.

The award is intended to cover the expenses, either wholly or in part, of such trainees who wish to come to the United Kingdom or the Republic of Ireland, for a short period of further study, research or clinical training.

Applicants must submit an account of their previous psychiatric experience and their training needs, and describe the way in which they consider that the use of the Fellowship might benefit the psychiatric services in their home countries.

All applications must include the following:

(a) a curriculum vitae (b) the names and addresses of two referees, who are aware of the applicant's work and aspirations, and who can attest to his/her fluency in English

(c) a proposal as to how and where the applicant might spend his/her time, with confirmation, if possible, from the host centre(s) in the United Kingdom or the Republic of Ireland

(d) an account of any original research, published or unpublished papers or reviews.

Applications for the Travelling Fellowship should be submitted to the Dean of the College by 30 September 1992, and will be assessed by the Dean in consultation with the Overseas Liaison Committee.

Members and Fellows of the College working in countries overseas are requested to bring the Fellowship to the attention of their trainees.

\section{Dr Ahmed Osman Siraj - An appeal}

The fundamentalist military government of Sudan is notorious for its abuse of human rights. Its severe laws, discriminations and punishments have been condemned by human rights organisations all over the world.

Among its victims are a large number of doctors, who have been detained without trial and tortured (often in "secret houses"). One doctor died in April 1991, following torture in prison. Another was sentenced to death, but finally released in response to international protest. Most, but by no means all, are no longer in prison. The great majority have not been allowed to return to work and many have fled the country.

One of those still in prison is Dr Ahmed Osman Siraj, President of the Sudanese Society of Psychiatrists, a Senior Lecturer in the University of Khartoum and a Member of our College. We have been attempting to gain his release, with a view to his coming to the UK for a period of personal and educational recuperation. So far, we have had no success.

The regime has shown itself to be sensitive to world opinion. May we therefore call on Journal readers worldwide to write, on behalf of Dr Siraj, to the President of Sudan, Lieutenant-General al-Bashir, People's Palace, P.O. Box 281, Khartoum, and to their local Sudanese embassies. (The address of the Sudanese Embassy in London is Cleveland Row, SW1.)

Professor A. C. P. Sims President
Dr J. L. T. BIRLEY

Immediate Past President
Dr Thomas BewLey

Past President 